\title{
Margaret McCartney: Industry's interest in diagnosing more dementia
}

\author{
(C) (1) O OPEN ACCESS
}

Margaret McCartney general practitioner, Glasgow

The ongoing charge is that dementia is being underdiagnosed. The UK Alzheimer's Society's chief said recently, "By next year, 850000 people in the UK will have dementia ... we will not [stand by while] over 400000 people living with [undiagnosed] dementia are left in the dark." And the health secretary, Jeremy Hunt, has said that "for too long diagnosis rates have been shockingly low."

But what is dementia's true prevalence? The first Cognitive Function and Ageing Study predicted that $8.3 \%$ of over $65 \mathrm{~s}$ would have dementia by 2011. A 2013 follow-up, however, found an actual prevalence of $6.5 \% .^{3}$ This translates to 670000 cases in England and Wales, rather than an expected 884000.

The Alzheimer's Society does not use this real world evidence, though. Instead it commissioned a report using Delphi methods to estimate a prevalence of $7.1 \%{ }^{4}$ This uses expert views on existing evidence (including the Cognitive Function and Ageing Study) and is less reliable than properly powered primary research.

The society should emphasise the uncertainty in these numbers when citing them. At a practice with 2000 people older than 65 , a prevalence of $8.3 \%$ rather than $6.5 \%$ would mean 166 people with dementia, rather than 130 .

Do all of these "missing" diagnoses actually exist? Must all diagnoses now be instant? What happened to the judicious use of time as a diagnostic tool? Faster diagnostic tests will simply mean more false positives.

Might other factors be driving more, and not necessarily better, diagnosis? The society is "working in partnership" with the drug company Lilly UK to supply leaflets to the public, titled Worried About Your Memory? ? $^{5}$ together they have also produced a document called Patient Journey. And Lilly, along with AstraZeneca, recently announced phase II/III trials of a new drug for use in "early Alzheimer's."

Phil Freeman, spokesman for the Alzheimer's Society, told The $B M J$ that "commitment to people with dementia is our only interest in this situation" and that the society had "one of the most robust policies ... governing financial contributions from the pharmaceutical industry," which can make up no more than
$5 \%$ of total annual income. In 2013, contributions from industry made up $0.13 \%$ of the society's income, $£ 35000$ of which came from Lilly and is used to distribute 1.25 million leaflets twice a year.

In the foreword to Patient Journey, Lilly writes of the need for "early" diagnosis, ${ }^{6}$ when a better word might be "timely."7 This is not surprising, however, as Lilly says that the "poor uptake of new medicines" presents a challenge. "The significance and value of an early and accurate diagnosis for people with dementia," the company goes on to say, is "poorly understood" but "will become increasingly important as new treatments evolve as a result of scientific innovation.",

These treatments don't yet exist—but we seem to be acting as though they do. Doctors and patients have recently said that they want to get rid of financial incentives that were brought in for diagnosing dementia. ${ }^{9}$ But what of the pressure from industry, partnering with charities so close to the creation of policy?

Competing interests: I have read and understood the BMJ policy on declaration of interests and declare the following interests: I'm an NHS GP partner, with income partly dependent on Quality and Outcomes Framework points. I'm a part time undergraduate tutor at the University of Glasgow. I've written a book and earned from broadcast and written freelance journalism. I'm an unpaid patron of Healthwatch. I make a monthly donation to Keep Our NHS Public. I'm a member of Medact. I'm occasionally paid for time, travel, and accommodation to give talks or have locum fees paid to allow me to give talks but never for any drug or public relations company. I was elected to the national council of the Royal College of General Practitioners in 2013.

thebmj.com Personal View: Target diagnosis rates in primary care are misleading and unethical (BMJ2014;349:g7235, doi:10.1136/bmj.g7235) Provenance and peer review: Commissioned; externally peer reviewed.

Hughes J. Margaret McCartney: Dementiagate - what was the role of the Alzheimer's Society? Rapid response. 31 Oct 2014. www.bmj.com/content/349/bmj.g6446/rapidresponses.

2 Ramesh R. Doctors told to improve dementia diagnosis rates. Guardian 15 May 2013. www.theguardian.com/society/2013/may/15/doctors-told-improve-dementia-diagnosis. 
3 Matthews FE, Arthur A, Barnes LE, Bond J, Jagger C, Robinson L, et al; Medical Research Council Cognitive Function and Ageing Collaboration. A two decade comparison of prevalence of dementia in individuals aged 65 and older from three geographical areas of England: results from the Cognitive Function and Ageing Study I and II. Lancet 2013;382:1405-12.

4 Alzheimer's Society. Dementia UK: update. Nov 2014. www.alzheimers.org.uk/site/scripts/ download_info.php?filelD=2323.

5 Alzheimer's Society. Worried about your memory? Aug 2013. www.alzheimers.org.uk/ site/scripts/download_info.php?downloadID $=52 \&$ fileID $=339$.

6 Alzheimer's Society. The "patient journey" for people with Alzheimer's disease. 2012. www.alzheimers.org.uk/site/scripts/download_info.php?downloadID=1291.

7 Burns A, Buckman L. Timely diagnosis of dementia: integrating perspectives, achieving consensus. July 2013. www.dementiaaction.org.uk/assets/0000/3808/NHS England BMA Diagnosis Consensus.pdf.
8 Dementia Action Alliance. Members: Lilly UK. 23 Oct 2014. www.dementiaaction.org.uk/ members_and_action_plans/89-lilly_uk.

9 Brunet M, Murphy K, Heath I, Britton B, Chand K, Marciano SA, et al. Open letter to Simon Stevens, NHS chief executive, and Alistair Burns, national clinical lead for dementia. BMJ 2014;349:g6666.

Cite this as: BMJ 2014;349:g7480

This is an Open Access article distributed in accordance with the Creative Commons Attribution Non Commercial (CC BY-NC 4.0) license, which permits others to distribute, remix, adapt, build upon this work non-commercially, and license their derivative works on different terms, provided the original work is properly cited and the use is non-commercial. See: http://creativecommons.org/licenses/by-nc/4.0/. 